\title{
Appraising and developing ST-X field: determination of uncertainties by DST analysis
}

- Vu Viet Hung ${ }^{1}$

- Mai Cao Lan ${ }^{2}$

${ }^{1}$ Lam Son Joint Operating Company

${ }^{2}$ Department of Drilling and Production, Faculty of Geology and Petroleum Engineering- Ho Chi Minh city University of Technology, VNU-HCM

(Manuscript Received on July 05 ${ }^{\text {th }}$, 2015; Manuscript Revised on September $30^{\text {th }}, 2015$ )

\section{ABSTRACT}

A subsurface uncertainties is a possible future event, which, if occurs, would affect project objectives either negatively or positively. For any given model or event, the uncertainty is the range of variation of the component parts and possible outcomes. It could be quantified approximately by either analytical model or in a more cumbersome one such as numerical approach.

This paper summarizes thedetermination ofuncertainties by DST analysis in appraising and developing the ST-X gas condensate field, which is offshore Vietnam in Block 15-1O. Drill Stem Test (DST) results show that the S field has moderate to low permeability, multiple flow boundaries/barriers, and at least 2 PVT regions.

To understand the impact of these and other important reservoir parameters on ultimate gas and condensate recovery and well count, the uncertainties has to be well evaluated and understood.

The study demonstrates that there is a wide range of possible ultimate gas and condensate recoveries and well counts. The top causes for this wide range are permeability and flow boundaries/barriers. In addition to the subsurface risks, drilling cost of a ST-X well is very high. The high well cost in combination with the field being offshore, having low permeability and possibly numerous reservoir compartments dramatically increase the risk of a full field development.

Key word: uncertainty analysis, well test analysis, history matching, sensitivity analysis.

\section{INTRODUCTION}

The ST-X field is in the Cuu Long basin with approximately $155 \mathrm{~km}$ east of Vung Tau, $62 \mathrm{~km}$ offshore Vietnam, in 66 meters of water (Figure 1). Four wells have been drilled in the ST-X field to date (Figure 2).
The first wildcat well,Well-Alies in the South East corner of Block 15-1O. Tests showed hydrocarbons flowing from three intervals in the Oligocene Clastics.

The second well (or the first appraisal well) 
Well-Bwas drilled to evaluate the faulted and fractured basement reservoir, as well as, the Oligocene sandstones sequences.

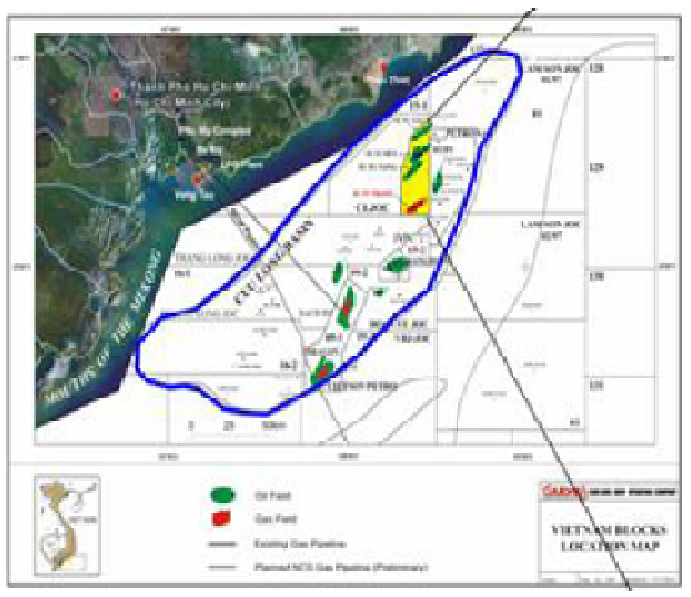

Figure 1. ST-X Location Map

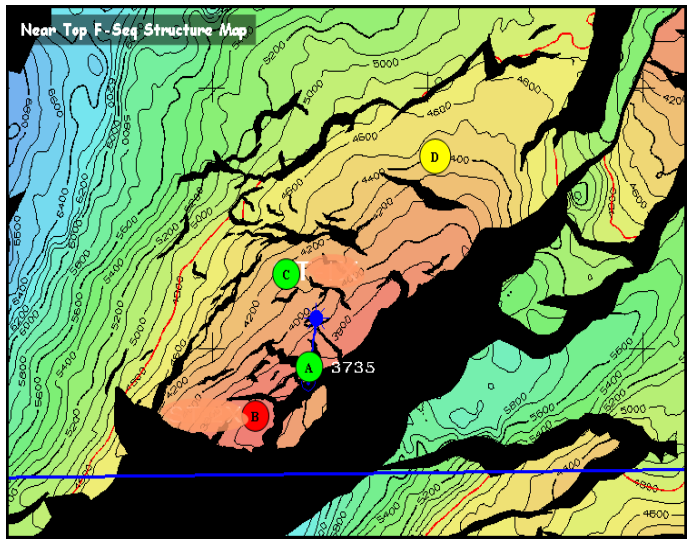

Figure 2. ST-X Wells Location

The second appraisal well,Well-Cwas drilled to evaluate the down flank extent of the sand sequences and an untested fault block.

The Well-Dwell was drilled to test the Oligocene clastics on the northern flank of the ST-X structure.

\section{LITERATURE REVIEW}

\section{Reservoir Uncertainties}

Static reservoir properties are such as Net Sand, Sand Porosity and Oil Saturation. This includes the uncertainty in petrophysical derivation of well-logs, plus the lateral distribution of the static reservoir properties across the reservoir (controlled by the depositional facies scenario). The major impact of Static Reservoir properties uncertainty is on STOIIP and the reserve output. Permeability, cross plotting of the porosity and permeability data derived from core, well test, mini-DST, and MDT/RCI indicates scope for alternative regression lines to fitted through this data. Theoretically, two main categories of uncertainties that can potentially impact the value of the field development

- Static Uncertainties mainly impacting STOIIP (from structural, depositional and fluid contact uncertainty)

- Dynamic Uncertainties impacting long term reservoir sweep and productivity. These categories of uncertainties combined describe a range of ultimate recoveries and production forecasts.

\section{Drill Stem Testing (DST)}

Well testing has progressed to become one of the most powerful tools for determining complex reservoir characteristics. It emphasizes the need for both a controlled downhole environment and high-performance gauges, which have made well testing a powerful reservoir description tool. Generally the Well Testing Interpretation results are: (transmissibility)

- The well production capacity (well damage)

- The reservoir limits (reservoir porous volume)

- The reservoir specific behaviors

During a well test, a particular flow rate history is applied to a well, and the resulting pressure changes are recorded, either in the same well (typically) or in a nearby well interference test. 


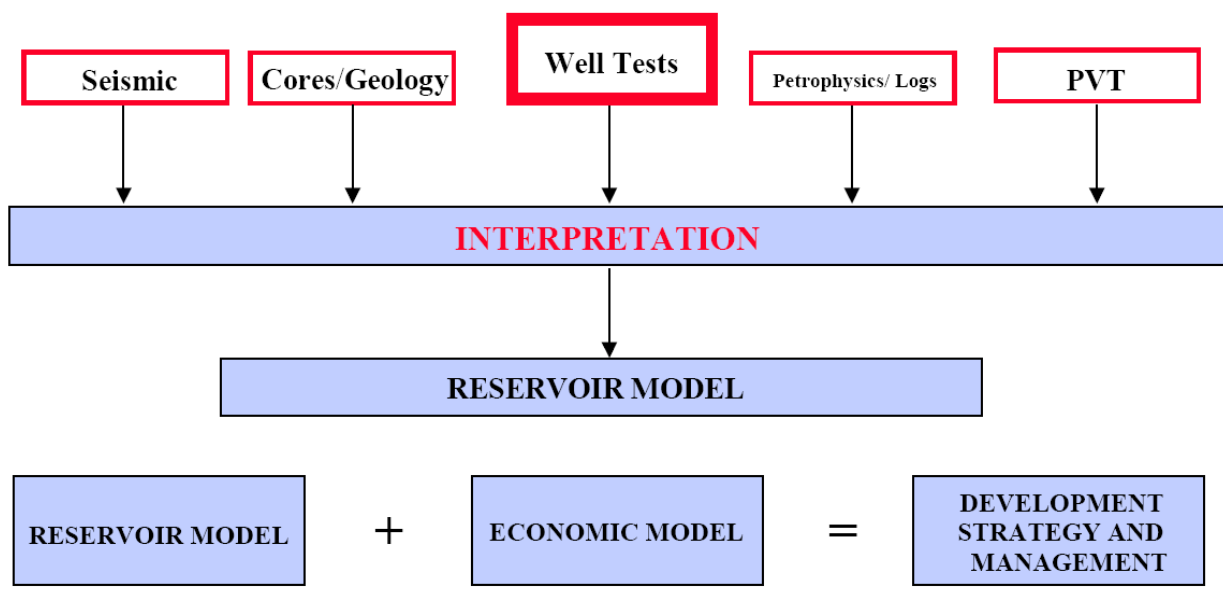

Figure 3. Well Testing is Indispensable part of Reservoir Description and Management

From the measured pressure response, and from predictions of how reservoir properties influence that response, an insight can be gained into those reservoirs properties. In order to make these predictions, it is necessary to develop mathematical models of the physical behavior taking place in the reservoir.

In view of modeling, good quality DST data promises bringing reliable dynamic modeling result. Condition is that the calibration approach shall be reasonable to capture the variation in reservoir property with no over or under its estimation potential. A systematic approach of using dynamic model to assess the variation of well test interpretation result to the range of output recovery factor as depicted in Figure 3.

\section{Methodology}

Analysis and evaluation of uncertain factors include three basic steps: identification of uncertain factors, determined domain of uncertain factors and screening uncertain factors. Within the scope of this study, step 1 in the process of defining the elements are unlikely to be present. In particular, the uncertainty factors are identified through interpretation of dynamic data during testing. These factors include : K, Skin, Tran, Fluid, Boundary, Condensate blockage, Porosity, Fault, absolute permeability, rock compression ...

Based on the uncertainty factors have been identified, the suspect may affect the model simulation results. These uncertainties may be related to geological and technological factors as discussed above. These factors have been the strongest impact on model outputs. These factors are selected based on the characteristics of each reservoir, as well as on the experience of the engineer. The determination of value domain must be consulted by the experts of geology and reservoir engineering.

Besides, the methodology has been based upon reservoir simulation predictions using the available simulation models which have been calibrated to DST data. The reasonable case sensitivities have been performed through variation of various parameters including OIIP changes, well counts and static \& dynamic properties.

The work flow for dynamic modeling work is essential in the sense that it allows a systematic approach for any modeling work. 
Two major groups in the process includes DST calibration such that the model will be tuned to testing data to a certain confident level, then the well placement steps ensure capturing potential productive areas, determine optimum number of well as well as its trajectory, perforation policy and so on. The last step in the process is to analyze and sort out the uncertainty factor in the Tornado chart prior to come up with a final recovery factors.

\section{RESULTS AND DISCUSSION}

\section{Appraisal wells results}

DST's wereconductedon the Well-A(D, E and F Sand); Well-B(Basement); Well-C(E and F Sand) and Well-D(E sand)wells. Table 1 summarizes the flow properties determined from these tests for each well and sand sequence.In addition to the PVT data obtained from the DST's (Table 2), MDT data also provides an understanding of how the PVT properties may vary within the reservoir (Figure 4). They indicate that potentially three PVT regimes may exist in the field.

Table 1. Flow Properties Seen on DST's

\begin{tabular}{|c|c|c|c|c|}
\hline & Well / DST & Perm & $\begin{array}{l}\text { Pressure } \\
\text { drop }\end{array}$ & Remark \\
\hline \multirow{2}{*}{ Well-A } & $\begin{array}{l}\text { DST\#? } \\
\text { F sequence }\end{array}$ & High & Small & Boundary effected \\
\hline & $\begin{array}{l}\text { DSTH3 } \\
\text { E sequence }\end{array}$ & High & Small & Boundary effected \\
\hline Well-B & $\begin{array}{l}\text { DST } \# 2 \\
\text { Basement }\end{array}$ & Very Low & & $\begin{array}{l}\text { Pressure on trend with overlying } \\
\text { F sand. Very low Perm }\end{array}$ \\
\hline \multirow{2}{*}{ Well-C } & $\begin{array}{c}\text { DST } 1 \\
\text { F sequence }\end{array}$ & Very Low & Large & Boundaries effected \\
\hline & $\begin{array}{c}\text { DsTH2 } \\
\text { E sequence }\end{array}$ & Very Low & Large & Condensate Blockage \\
\hline Well-D & $\begin{array}{l}\text { DST } 2 \\
\text { E sequence }\end{array}$ & Very Low & Large & Boundaries effected \\
\hline
\end{tabular}

Table 2. PVT Data Obtained From Exploration / Appraisal Wells

\begin{tabular}{|c|c|c|c|}
\hline Well & Formation & Fluid & Pb/Pd \\
\hline Well-A & E & Gas & $\sim 4800$ \\
\hline Well-B & Basement & Gas & $\sim 4200$ \\
\hline Well-C & E & Gas & $\sim 7600$ \\
\hline Well-C & F & Gas & $\sim 5000$ \\
\hline Well-D & E & Liquid & $\sim 7100$ \\
\hline
\end{tabular}

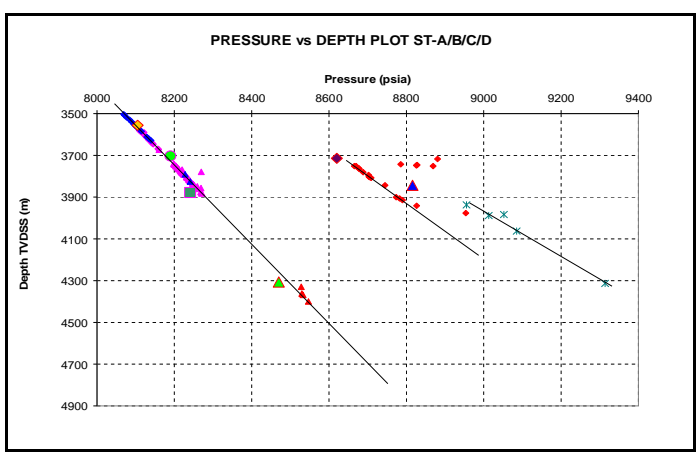

Figure 4. MDT Data Obtained From ST Exploration / Appraisal Wells 


\section{DETERMINATION OF UNCERTAINTIES BY DST ANALYSIS}

Derivative analysis was performed on the initial build up, main flow period and main build up for all well of ST Field.For simplicity, only the gas rates and bottom hole pressure have been input into the analysis. Pressure analysis was performed using the following set of input data as below.

Gas volume factor : $0.00370 \mathrm{ft} 3 / \mathrm{scf}$; Water Compressibility: 4.3466e-6

Thickness: 163 TVD ft; Porosity: 10\%; Water Saturation: $10 \%$; Rw: $0.177 \mathrm{ft}$

Gas Compressibility: 4.6950e-5; Total Compressibility: 4.6799e-5

Formation Compressibility: 4.1093e-6; Gas viscosity : $0.0497 \mathrm{cp}$

An example showing the detail of DST analysis for DST\#3 of well ST-C. The general overview of the pressure data recorded during DST\#3 is shown in the Figure 5.

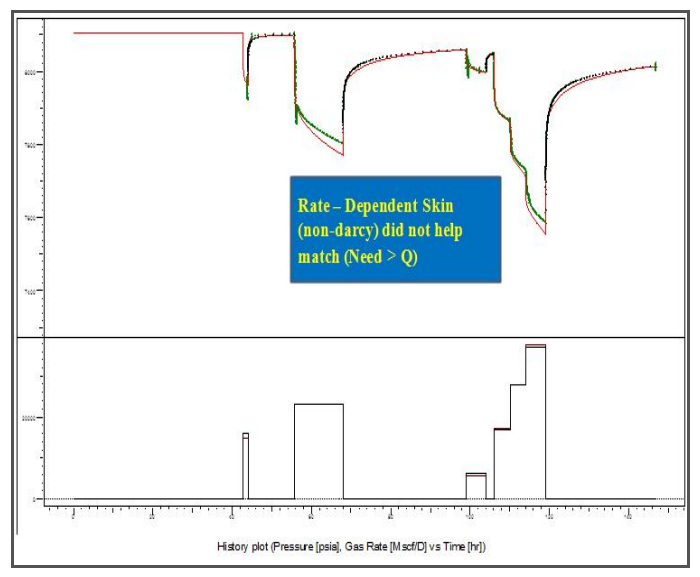

Figure 5. Gas Rate and Pressure for Analysis in DST\#3

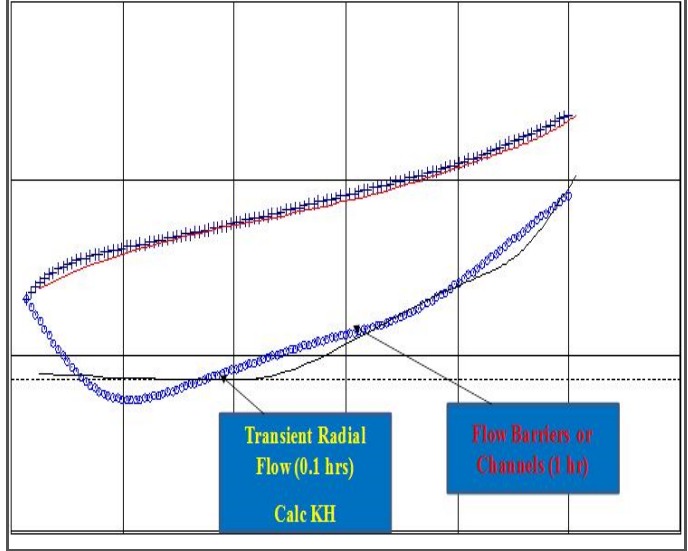

Figure 6. $\log$ - Log Plot of the final build up (single layer)

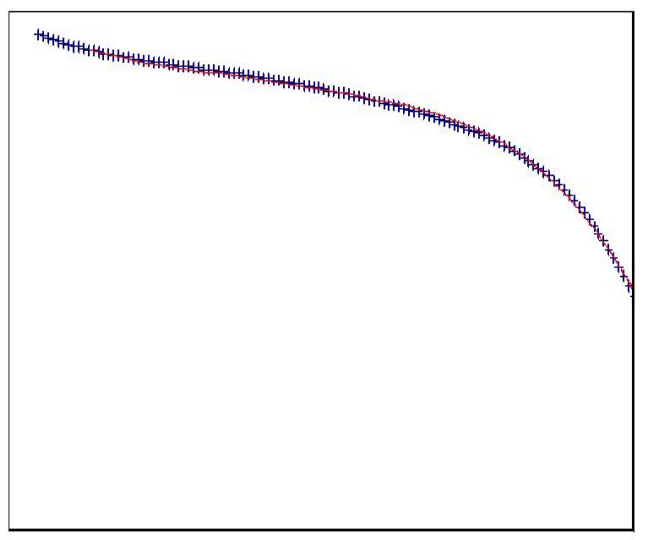

Figure 7. Semi- Log plot of the final build up(single layer)

Derivative analysis was performed on the main build up period. This derivative is shown in Figure 6 and 7: the $\log -\log$ plot and semi $\log$ plotof the final build up with single layer model. By matching this plot, derivative pressure curve of this DST indicates a radial flow period followed by a period that appears to be effected by boundaries. However, late time period of derivative curve still has been no good matching due to single layer is only sensitive with boundary close to the well.

This pressure behavior suggests that two boundaries were encountered. A good match to 
the boundary effects can be obtained by change multi layer and boundary model (parallel faults).

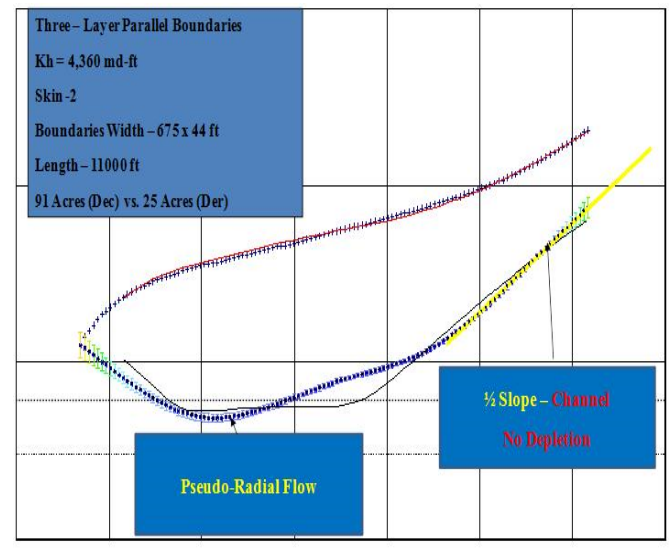

Figure 8. Log- Log plot of the final build up(three layer with parallel boundary)

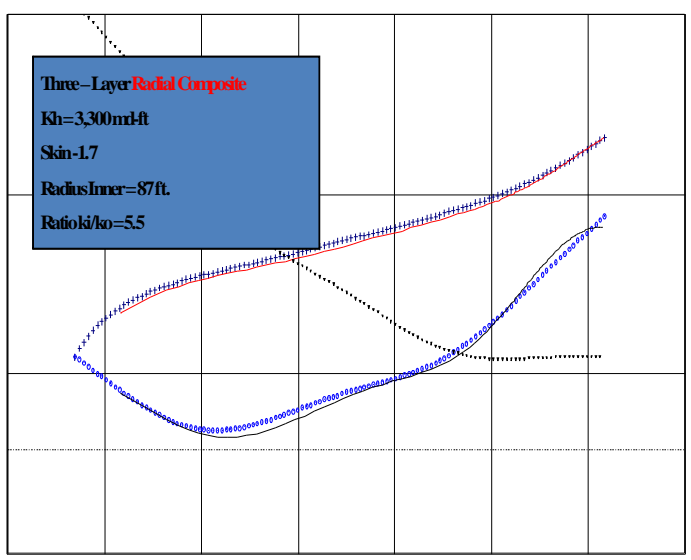

Figure 9. Log- Log plot of the final build up(three layer with radial composite)

The simplest solution that is able to achieve satisfactory matches on both the derivative and the full flowing period is shown above. This is a radial composite system with parallel faults at 675 feet and 44 feet from the well. Permeability in the well is somewhat uncertain due to the uncertainty in picking radial flow.By matching this plot and attempting to match the full history an attempt at arriving at values for kh, Skin and Cs can be made.

\section{CONCLUSIONS AND RECOMMENDATIONS}

Theresults of this work show that there remains significant reservoir uncertainties in the ST-X field and thesimulated recovery factor can vary greatly. The well count forthe good reservoir permeability and connectivity scenario is much lower than for the case where the reservoir has poor permeability and connectivity.Additionally, during the exploration and appraisal phase of the ST-X field, it was found that the drilling cost of a ST$\mathrm{X}$ wells are very high. The high drilling cost combined with the field being offshore and the reservoir having both low permeability and potentially large numbers of reservoir flow boundaries make a full field development a high risk endeavor.

For these reasons an Early Production Systemis recommended to reduce the development risk. In addition to generating revenue by selling the produced condensate and gas, the production data will improve the understanding of the field'spermeability distribution and connectivity. The reservoir information obtained from the Early Production System will be vital input for further consideration of a full field development plan ofST-X Field. 


\section{Thẩm lượng và phát triển mỏ ST-X - Xác định thông số rủi ro và thách thức bằng phân tích thử vỉa}

- Vũ Việt Hưng

Công ty điều hành chung Lam Sơn

- Mai Cao Lân

Bộ môn Khoan \& Khai thác Dầu khí, Đại học Bách khoa, ĐHQG-HCM

\section{TÓM TẮT}

Mỏ khí ngung tụ ST-X là một trong các mỏ dầu khí lớn nằm trong lô 15-10 ngoài khoi Việt Nam. Đánh giá trũ luợng dầu khí tại chố cho thấy đủ khả năng đưa mỏ và phát triển. Kết quả thử via chỉ ra mỏ ST-X có độ thấm trung bình thấp, bất đồng nhất, cao. Các giếng khoan mỏ ST-X không nhũng có rủi ro về địa chất mà còn điều kiện ngoài khơi đã làm tăng tính rủi ro cho phát triển mỏ. Vấn đề lớn đặc ra là làm sao phát triển mỏ này với khả năng thu hồi cao nhất mà chi phi đầu tu thấp nhất.

Bài báo tóm luợc kết quả đánh giá về việc nhận diện và xác định nhũng yếu tố không chắc chắn thông qua minh giải số liệu thử vỉa. Qua đó sẽ đánh giá ảnh hwởng của các yếu tố rủi ro lên hệ số thu hồi dầu - khí. Kết quả sẽ giúp đưa ra phuoong huoóng phát triển mỏ khi ngung tụ với cực tiểu rủi ro và cực đại thu hồi dầu khí.

Số liệu thư via của các giếng thăm dò đã chi ra nhiều yếu tố không chắc chắn: độ thấm thấp, nhiều biên không thấm, vùng khóa bởi khí ngung tu và via có ít nhất 2 vùng đặc tính lưu
chất...Dựa trên các dũ liệu có giá trị, có nhiều câu hỏi cần phải được trả lời trước khi đưa mỏ vào phát triển.

1. Mức độ không chắc chắn nhu thế nào với các thông số via

2. Làm thế nào để xác định các yếu tố không chắc chắn

3. Yếu tố nào là không chắc chắn cao nhất

4. Anh hương của các yếu tố không chắc chắn này đến số lượng giếng và thu hồi khí, dầu ngung tu

5. Khoảng giá trị có thể có của thu hồi khí, dầu ngung tụ và số lượng giếng

6. Phương án nào phát triển mỏ tốt nhất

Trong phạm vi nghiên cứu sẽ trả lời các câu hỏi về xác định các yếu tố không chắc chắn và thông số nào ảnh hưởng cao nhất lên khả năng thu hồi khí, dầu ngung tu và số lương giếng. Tù đó đề ra phuơng huoóng phát triển mỏ tối ưu.

Tù khóa: phân tích tính bất định, phân tích thử giếng, phân tích ảnh hưởng, lịch sủ khai thác. 


\section{REFERENCES}

[1]. Robert c. Earlougher. "Advanced Well Test Analsys. Texas": Society of Petroleum Enginer, 1977.

[2]. Virine, L. and Rapley L.: "Decision and Risk Analysis Tools for the Oil and Gas Industry," paper SPE 84821 presented at the SPE Eastern Regional/AAPG Eastern Section Joint Meeting, Pittsburgh, Pennsylvania, U.S.A, Sept.6-10, 2003.

[3]. Ostebo, R.; Tronstad, L.; and Fikse, T.: "Risk Analysis of Drilling and Well Operations", Paper SPE/IADC 21952, Presented at the 1991 SPE/IADC Drilling Conference, Amsterdam, Holland, 11-14 March, 1991.

[4]. Coats, K.H: "Reservoir Simulation: State of the Art," JPT (Aug. 1982) 1633-42; Trans., AIME, 273.

[5]. Collins, R.E.: Flow of Fluids Through Porous Materials, Petroleum Publishing Co., Tulsa (1976) 254.

[6]. Kazemi, H., Vestal. C.R., and Shank, G.D.: "AN Efficient Multi component Numerical Simulator," SPEJ (Oct. 1978) 355-68.

[7]. Taylor, A.J.: "Computer Simulation of Condensate Reservoirs," paper presented at the 1983 OYEZ Science and Technology Services Ltd. North Sea Condensate Reservoirs and Their Development Conference, London, May 24-25.

[8]. Coats, K.H.: "Simulation of Gas Condensate Reservoir Performance," JPT (Oct. 1985) 1870-86; Trans., AIME, 279.
[9]. Todd, M.R. and Longstaff, W.J.: "The Development, Testing, and Application of a Numerical Simulator for Predicting Miscible Flood Performance," JPT (July 1972) 874-82: Trans., AIME, 253.

[10].Chu, C. and Trimble, A.E.: "Numerical Simulation of Steam Displacement - Field Performance Applications," JPT (June 1975)765-76

[11].Veatch, R.W. Jr. and Thomas, G.W.: "A Direct Approach for History Matching," paper SPE 3515 presented at the 1970 SPE Annual Meeting, New Orleans, Oct. 3-6.

[12].Jacquard, P. and Jain, A.: "Permeability Distribution from Field Pressure Data," SPEJ (Dec. 1956) 281-94; Trans., AIME, 234.

[13].Slater, G.E. and Durrer, E.J.: "Adjustment of Reservoir Simulation Models to Match Field Performance," SPEJ (Sept. 1971) 295-305; Trans., AIME, 251.

[14].Bishop, K.A., et al.: "The Application of Sensitivity Analysis to Reservoir Simulation," paper SPE 6102 presented at the 1976 SPE Annual Technical Conference and Exhibition, New Orleans, Oct. 3-6.

[15].Breit, V.S. et al.: "A Technique for Assessing and Improving the Quality of Reservoir Parameter Estimates Used in Numerical Simulators,", paper SPE 4546 presented at the 1673 SPE Annual Meeting, Las Vegas, Sept. 30-Oct.3 